Article

\title{
Genome-Wide Association Studies for the Concentration of Albumin in Colostrum and Serum in Chinese Holstein
}

\author{
Shan Lin ${ }^{1,+}$, Zihui Wan ${ }^{2,+}$, Junnan Zhang ${ }^{1}$, Lingna Xu ${ }^{1}$, Bo Han ${ }^{1}$ and Dongxiao Sun ${ }^{1, *}$ \\ 1 Key Laboratory of Animal Genetics and Breeding of the Ministry of Agriculture, National Engineering \\ Laboratory for Animal Breeding, Department of Animal Genetics and Breeding, College of Animal Science \\ and Technology, China Agricultural University, Beijing 100193, China; shanlin0820@163.com (S.L.); \\ cauzhangjn@163.com (J.Z.); Lingna_Xu@163.com (L.X.); bohan@cau.edu.cn (B.H.) \\ 2 Stae Key Laboratory of Agriobiotechnology, College of Biological Sciences, China Agricultural University, \\ Beijing 100193, China; 15810283027@163.com \\ * Correspondence: sundx@cau.edu.cn \\ + These authors contributed to the work equally and should be regarded as co-first authors.
}

Received: 29 September 2020; Accepted: 19 November 2020; Published: 26 November 2020

Simple Summary: The early death and illness of newborn calves result in enormous economic losses in the dairy industry. As the immune system has not been fully developed in neonates, the adequate intake of nutrients and immune substances in colostrum is essential for protecting neonates from infections in their early life. The term albumin refers to a group of multifunctional proteins that are important in anti-inflammatory and anti-oxidative reactions and can help calves against various infections. Albumin of bovine whey is derived from the serum; hence, the concentration of albumin in colostrum and serum could be important traits for the breeding of potential natural disease resistance in dairy cattle. Herein, genome-wide association studies (GWASs) were performed to identify the candidate genes associated with albumin concentrations in colostrum and serum to provide useful molecular information for the genetic improvement of disease resistance traits in dairy cattle.

\begin{abstract}
Albumin can be of particular benefit in fighting infections for newborn calves due to its anti-inflammatory and anti-oxidative stress properties. To identify the candidate genes related to the concentration of albumin in colostrum and serum, we collected the colostrum and blood samples from 572 Chinese Holstein cows within $24 \mathrm{~h}$ after calving and measured the concentration of albumin in the colostrum and serum using the ELISA methods. The cows were genotyped with GeneSeek $150 \mathrm{~K}$ chips (containing 140,668 single nucleotide polymorphisms; SNPs). After quality control, we performed GWASs via GCTA software with 91,620 SNPs and 563 cows. Consequently, 9 and 7 genome-wide significant SNPs (false discovery rate (FDR) at 1\%) were identified. Correspondingly, 42 and 206 functional genes that contained or were approximate to $( \pm 1 \mathrm{Mbp})$ the significant SNPs were acquired. Integrating the biological process of these genes and the reported QTLs for immune and inflammation traits in cattle, 3 and 12 genes were identified as candidates for the concentration of colostrum and serum albumin, respectively; these are RUNX1, CBR1, OTULIN, CDK6, SHARPIN, CYC1, EXOSC4, PARP10, NRBP2, GFUS, PYCR3, EEF1D, GSDMD, PYCR2 and CXCL12. Our findings provide important information for revealing the genetic mechanism behind albumin concentration and for molecular breeding of disease-resistance traits in dairy cattle.
\end{abstract}

Keywords: albumin; Chinese Holstein; genome-wide association study; inflammation; SNP 


\section{Introduction}

Improved animal health and resistance to pathogens is an increasingly important breeding objective in the dairy industry [1,2]. As the immune system of newborn calves is too weak to fight various infections, most diseases (for e.g., flu, diarrhea and omphalitis) and death events affecting calves occur in the first few days after birth [3-5]. Colostrum provides numerous nutrients, regulatory factors (cytokines, growth factors, enzymes and hormones), immune factors (immunoglobulins) and crucial proteins (albumin) to guarantee the health of the newborn calves [6,7]. Albumin is synthesized by hepatocytes and penetrates into the milk through the epithelial tight junction from the blood plasma [8-11]. The physiological and pathophysiological functions of albumin are relatively well known, such as maintaining the osmotic pressure and having an anti-oxidizing effect during inflammatory reactions [12-14]. In dairy cattle, the albumin concentration has been found to be much higher in the first milked colostrum $(1.21 \pm 0.44 \mathrm{mg} / \mathrm{mL})$ when compared to reported milk levels of $<0.2 \mathrm{mg} / \mathrm{mL}$ [15]. Previous studies have shown that the concentration of albumin in the milk increased during functional transitions from lactation to involution and during inflammation in cows [11,14,16-22], sheep [23] and goats [24]. During mastitis, the mammary gland is exposed to a high level of free radicals, and albumin might enhance the anti-oxidant defenses of the glands [13,25]. Therefore, the albumin concentration of colostrum and serum offers a potential possibility as one of the indices for resistance breeding to decrease the mortality of newborns in dairy cattle.

The concentration of albumin is a typical quantitative trait [26]. Previous studies in humans have reported heritability estimates of $0.10-0.24$ and $0.30-0.39$ for glycated and excreted albumin, respectively $[27,28]$. In dairy cattle, heritability is relatively lower $(0.13 \pm 0.09)[29,30]$. In early-lactation dairy cows, serum albumin has moderate heritability $(0.27 \pm 0.06)$ [31].

A genome-wide association study (GWAS) is a practical approach for the high-resolution mapping of loci controlling quantitative traits and has been widely applied in domestic animals [32]. In dairy cattle, a large number of previous GWASs have been performed to detect the genetic markers, candidate genes and QTLs for milk yield, milk protein and fat [33-36], milk fatty acids [37], mastitis [34,38-40], reproduction [35], body conformation [35] and immunoglobulin concentration [36,41]. However, so far there is only a limited number of studies that have investigated the candidate genes for albumin concentration in dairy cattle or even in other species. In this study, we conducted GWASs to identify the significant single nucleotide polymorphisms (SNPs) and candidate genes for the concentration of colostrum and serum albumin and provide information for molecular breeding to improve the resistance or tolerance to pathogens of newborns in dairy cattle.

\section{Materials and Methods}

\subsection{Animals and Phenotypes}

Blood, colostrum and hair follicle samples were collected in the first milking within $24 \mathrm{~h}$ after calving from 572 Chinese Holstein cows (0-6 h: 481 cows; 6-12 h: 38 cows; 12-18 h: 39 cows; and 12-24 h: 14 cows). All of the cows were from 10 dairy farms of the Beijing Dairy Cattle Center and the Beijing Sunlon Livestock Development Company Limited (herd 1: 90 cows; herd 2: 5 cows; herd 3: 88 cows; herd 4: 92 cows; herd 5: 58 cows; herd 6: 47 cows; herd 7: 75 cows; herd 8: 56 cows; herd 9: 19 cows; and herd 10: 42 cows). Cows were in parity of 1 to 4 and were the offspring of 44 sires. Cows were 23-72 months old at the time of calving. The whole procedure for collecting the blood, colostrum and hair follicle samples was carried out in strict accordance with the protocol approved by the Animal Welfare Committee of China Agricultural University (permit number: DK996).

The concentration of albumin of every colostrum and serum sample was measured by commercial ELISA kits (Bovine Albumin ELISA Quantitation Set, E10-113, Bethyl Laboratories, Montgomery, TX, USA). Concentrations were $\log _{10}$-transformed to follow a normal distribution. 


\subsection{Genotypes and Quality Control}

The extraction of genomic DNA from the hair follicles of the 572 cows was carried out using a QIAamp ${ }^{\circledR}$ DNA Mini Kit (QIAGEN, Valencia, CA, USA). Then the extracted DNA was genotyped by a GeneSeek GGP_HDv3 chip (including 140,668 SNP markers: GeneSeek, Lincoln, Dearborn, MI, USA).

Quality control was conducted on PLINK 1.90 software and the filtering processes were as follows: Firstly, samples with genotyping $<95 \%$ of the SNPs were deleted; then, SNPs with call rates $<90 \%$, minor allele frequencies (MAF) $<0.1$ and Hardy-Weinberg equilibrium (HWE) $p$-values $<10^{-6}$ were discarded [42,43]. Thus, 563 individuals with 91,620 SNPs were kept for further analysis (Supplementary Files 1 and 2).

\subsection{Statistical Analysis}

The association analysis for each SNP was implemented independently for the albumin concentration of colostrum and serum with the following mixed linear model:

$$
\mathbf{y}=\boldsymbol{\mu}+\mathbf{b X}+\mathbf{f M}+\mathbf{g}+\mathbf{e}
$$

where $\mathbf{y}$ is the vector of the phenotype of the log-transformed corrected concentration of albumin for 563 cows; $\mu$ is the vector of the overall mean; $\mathbf{b}$ refers to fixed effects, including herd, parity, time from calving and season of calving; $\mathbf{X}$ is the incidence matrix of $b$ to $y ; \mathbf{f}$ is the vector of the additive effect of the candidate SNP to be tested for association; $\mathbf{M}$ is the vector of the genotypes for the SNP, coded as $0=\mathrm{BB}, 1=\mathrm{AB}$ and $2=\mathrm{AA}$; $g$ is the vector of the polygenic effect with $\mathrm{g} \sim \mathrm{N}\left(0, \mathrm{G} \sigma_{\mathrm{g}}{ }^{2}\right)$, where $\mathrm{G}$ is the genomic relationship matrix between pairs of individuals from all of the SNPs' 30 chromosomes, including the $\mathbf{X}$ chromosome [44]; $\sigma_{\mathrm{g}}{ }^{2}$ is the additive variance; and $\mathrm{e}$ is the vector of the residual effects with $\mathrm{e} \sim \mathrm{N}\left(0,0, \mathbf{I} \sigma_{\mathrm{e}}^{2}\right)$, where $\sigma_{\mathrm{e}}^{2}$ is the residual error variance.

The GWASs were implemented with GCTA v1.90.2 software, which estimates the variance explained by all of the SNPs on a chromosome or on the whole genome for a complex trait [44]. As Bonferroni correction is deuced strict and may cause false negative results [45], we used the false discovery rate (FDR) method to set the $p$-value threshold $[46,47]$. The genome-wide threshold value was calculated according to an FDR of 0.01 with the following formula:

$$
\mathrm{P}=\mathrm{FDR} \times \mathrm{n} / \mathrm{l}
$$

where $\mathrm{n}$ is the number of the SNPs with $p<0.01$ in the GWAS results for the concentration of colostrum or serum albumin, and 1 is total number of SNPs analyzed. Then, we calculated the genomic inflation factor $\lambda$ value to evaluate the extent of the population stratification by GenABEL packages [48] in $R$ 3.6.0 (http://www.R-project.org/) [49]. Quantile-quantile (QQ) and Manhattan plots were drawn using the qqman package [50].

\subsection{Candidate Genes}

To further identify the positional candidate genes for albumin, the genes that contained or were close to $( \pm 1 \mathrm{Mbp})$ the significant SNPs were selected based on the Ensembl Bos taurus UMD3.1 database (http: //www.ensembl.org/index.html). The extracted genes were then submitted into DAVID Bioinformatics Resources (https://david.ncifcrf.gov) for the Gene Ontology (GO) terms and Kyoto Encyclopedia of Genes and Genomes (KEGG) pathway analysis to identify the biological processes that these genes are involved in. Simultaneously, we compared the physical position of these genes that contained or were adjacent to significant SNPs with the known QTLs for inflammation and immune-related traits in the Cattle QTL database (https://www.animalgenome.org/cgi-bin/QTLdb/BT/index). 


\section{Results}

\subsection{Phenotype and SNP Data Statistics}

In this study, 572 animals with the phenotype of an albumin concentration in the colostrum and serum were included for analysis. The original phenotypic data were $\log _{10}$-transformed to accomplish normality (Figure 1). The mean and the corresponding standard deviations for the original and corrected phenotype of the albumin concentration are shown in Table 1. After the quality control, 91,620 SNPs and 563 cows were obtained for the subsequent association analysis. The distribution of the SNPs on the genome is presented in Figure 2.
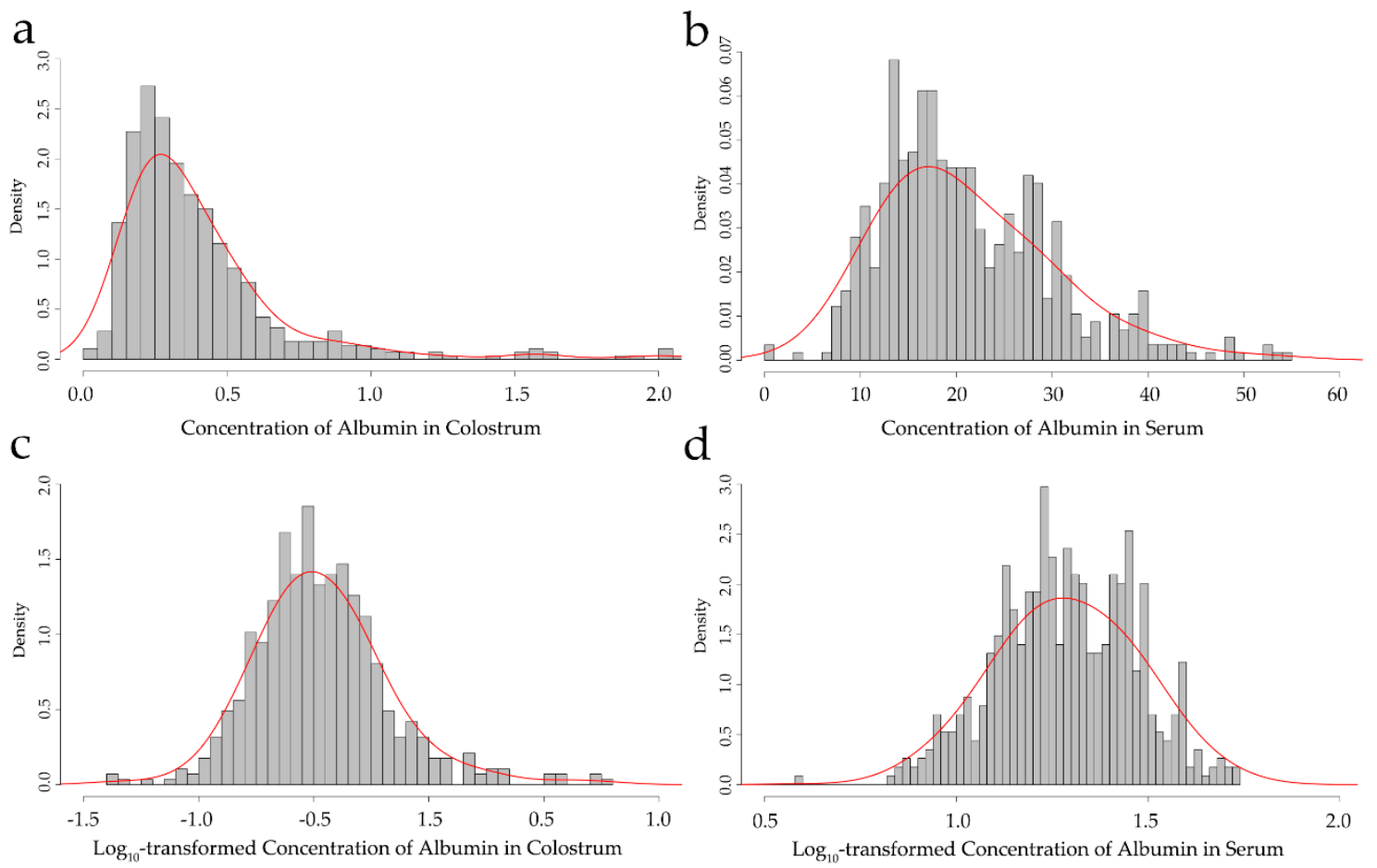

Figure 1. Frequency distribution of the concentration of albumin in colostrum and serum: $(\mathbf{a}, \mathbf{b})$ show the original colostrum and serum albumin concentrations; $(\mathbf{c}, \mathbf{d})$ show the $\log _{10}$-transformed colostrum and serum albumin concentrations.

Table 1. Descriptive statistics for the concentration of albumin in colostrum and serum; $n=572$.

\begin{tabular}{cccccccc}
\hline Traits $^{\mathbf{a}}$ & Arithmetic Mean $\mathbf{( m g} / \mathbf{m L})$ & $\mathbf{S D}^{\mathbf{b}}$ & Minimum & Maximum & $\mathbf{C V}^{\mathbf{c}}$ & Skewness & Kurtosis \\
\hline col & 0.454 & 0.555 & 0.040 & 6.180 & 1.224 & 6.065 & 46.956 \\
ser & 21.061 & 8.883 & 0.220 & 54.500 & 0.422 & 0.909 & 0.957 \\
${\text { col- } \log _{10}}_{\text {er- } \log _{10}}^{-0.466}$ & 0.291 & -1.390 & 0.790 & -0.625 & 0.737 & 2.213 \\
\hline
\end{tabular}

${ }^{a}$ col and ser = the concentration of albumin in colostrum and serum, respectively; $\log _{10}=\log _{10}$-transformed phenotypes; ${ }^{b}$ standard deviation; ${ }^{c}$ coefficient of variation. 


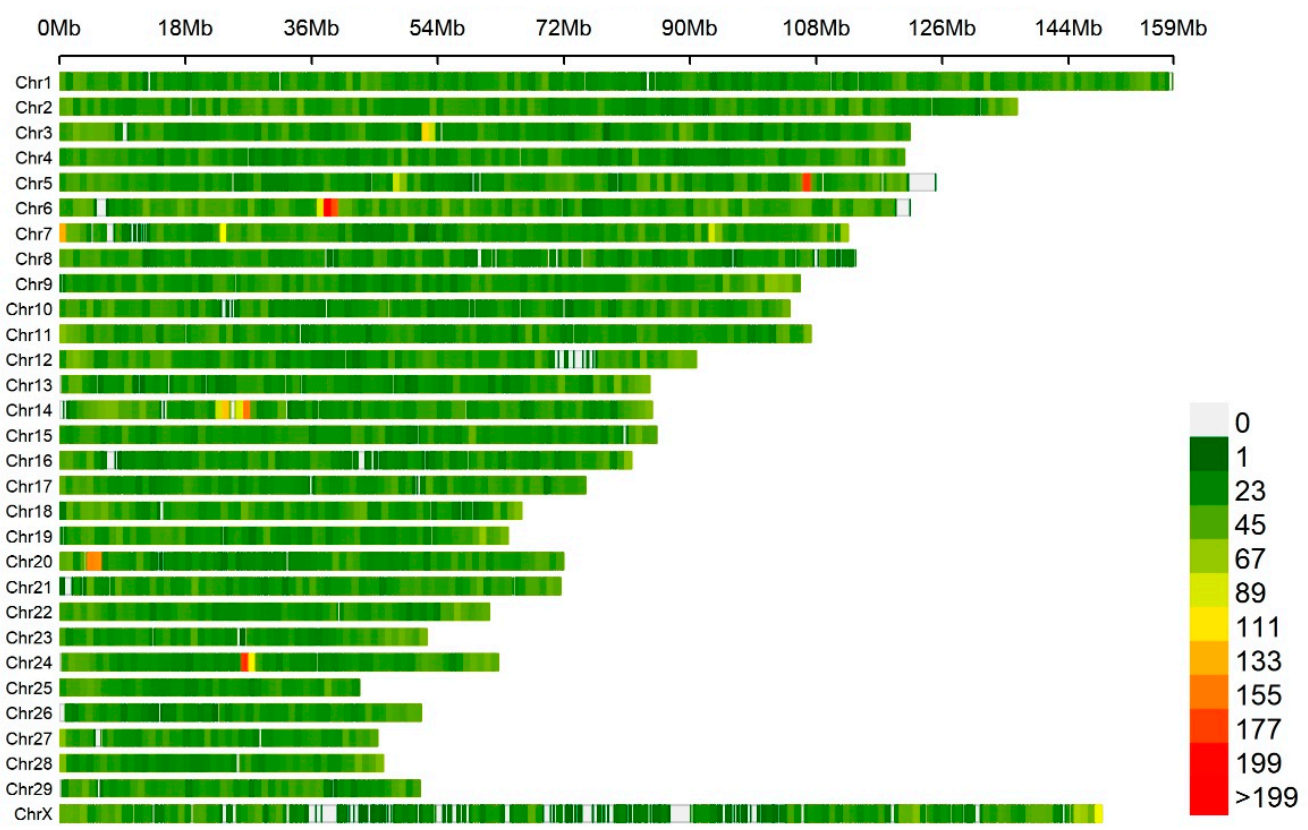

Figure 2. The SNPs' density distribution on 29 autosomes and the X-chromosome of the bovine genome. The horizontal axis (X-axis) shows the chromosome length (Mbp). SNP density was calculated per $1 \mathrm{Mbp}$ window. Different colors represent different SNP density levels.

\subsection{Genome-Wide Association Study}

According to the $p$-value of every SNP, the calculated inflation factor $(\lambda)$ was 0.983 and 1.004 for the concentration of colostrum and serum albumin, respectively, and the QQ plots (Figure 3) showed that the population stratification had been well corrected [51]. Consequently, nine significant SNPs were identified for concentration of albumin in colostrum at the genome-wide level (FDR at 1\%), located on Bos taurus autosome (BTA) 1: 149,246,858 bp (BovineHD0100043239); BTA 3: 118,061,120 bp (ARS-BFGL-NGS-75,987); BTA 17: 68,421,115 bp (ARS-BFGL-NGS-66,134); and BTA 20: 59,137,600—69,916,426 bp (BovineHD2000016546, BovineHD2000016866, BovineHD2000019816, BTB-00798071, ARS-BFGL-NGS-75636, and ARS-BFGL-NGS-114933) (Table 2).

For the albumin concentration in serum, seven genome-wide significant SNPs were detected (FDR at 1\%) on BTA 4: 10,737,673 bp (Hapmap39425-BTA-70290); BTA 7: 93,597,405 bp (BovineHD0700027327); BTA 7: 111,481,071 bp (BovineHD0700032536); BTA 14: 1,463,676 bp (Hapmap30381-BTC-005750); BTA 16: 30,440,171 bp (BovineHD1600008636); BTA 20: 39,761,822 bp (ARS-BFGL-NGS-73590); and BTA 28: 45,702,356 bp (BovineHD2800013250) (Table 2). The Manhattan plots for the concentration of albumin in colostrum and serum are shown in Figure 3. 
Table 2. The significant SNPs of the genome-wide association studies for the concentration of albumin in colostrum and serum.

\begin{tabular}{|c|c|c|c|c|c|c|c|c|c|}
\hline Traits $^{\text {a }}$ & $\mathrm{Chr}^{\mathrm{b}}$ & SNP & Position (bp) on UMD 3.1 & Major/Minor Allele & MAF $^{c}$ & SNP Effect & $\mathrm{SE}^{\mathrm{d}}$ & CGV(\%) & FDR-Corrected $p$-Value \\
\hline col & 1 & BovineHD0100043239 & $149,246,858$ & $\mathrm{C} / \mathrm{A}$ & 0.156 & 0.176 & 0.044 & 2.550 & $9.765 \times 10^{5}$ \\
\hline $\mathrm{col}$ & 3 & ARS-BFGL-NGS-75987 & $118,061,120$ & C/A & 0.127 & 0.207 & 0.052 & 3.188 & $7.258 \times 10^{5}$ \\
\hline $\mathrm{col}$ & 17 & ARS-BFGL-NGS-66134 & $68,421,115$ & $\mathrm{G} / \mathrm{A}$ & 0.379 & 0.137 & 0.035 & 2.869 & $9.248 \times 10^{5}$ \\
\hline $\mathrm{col}$ & 20 & BovineHD2000016546 & $59,137,600$ & $\mathrm{G} / \mathrm{A}$ & 0.420 & -0.136 & 0.034 & 2.869 & $9.506 \times 10^{5}$ \\
\hline $\mathrm{col}$ & 20 & BovineHD2000016866 & $60,034,418$ & $\mathrm{~A} / \mathrm{G}$ & 0.351 & 0.142 & 0.035 & 2.869 & $6.600 \times 10^{5}$ \\
\hline $\mathrm{col}$ & 20 & BovineHD2000019816 & $68,269,626$ & $\mathrm{~A} / \mathrm{G}$ & 0.179 & 0.191 & 0.043 & 3.506 & $9.442 \times 10^{5}$ \\
\hline $\mathrm{col}$ & 20 & BTB-00798071 & $68,605,103$ & $\mathrm{C} / \mathrm{A}$ & 0.107 & 0.243 & 0.055 & 3.506 & $1.513 \times 10^{5}$ \\
\hline $\mathrm{col}$ & 20 & ARS-BFGL-NGS-75636 & $69,893,541$ & $\mathrm{G} / \mathrm{A}$ & 0.146 & 0.199 & 0.048 & 3.188 & $4.329 \times 10^{5}$ \\
\hline $\mathrm{col}$ & 20 & ARS-BFGL-NGS-114933 & $69,916,426$ & $\mathrm{~A} / \mathrm{G}$ & 0.149 & 0.196 & 0.048 & 3.188 & $5.724 \times 10^{5}$ \\
\hline ser & 4 & Hapmap39425-BTA-70290 & $10,737,673$ & $\mathrm{~A} / \mathrm{C}$ & 0.414 & 2.241 & 0.560 & 3.062 & $6.282 \times 10^{5}$ \\
\hline ser & 7 & BovineHD0700027327 & $93,597,405$ & G/A & 0.396 & 2.450 & 0.610 & 3.607 & $5.881 \times 10^{5}$ \\
\hline ser & 7 & BovineHD0700032536 & $11,1481,071$ & $\mathrm{G} / \mathrm{A}$ & 0.163 & 3.451 & 0.763 & 4.091 & $6.032 \times 10^{5}$ \\
\hline ser & 14 & Hapmap30381-BTC-005750 & $1,463,676$ & $\mathrm{G} / \mathrm{A}$ & 0.328 & 2.432 & 0.616 & 3.273 & $7.814 \times 10^{5}$ \\
\hline ser & 16 & BovineHD1600008636 & $30,440,171$ & $\mathrm{G} / \mathrm{A}$ & 0.459 & -2.349 & 0.583 & 3.443 & $5.558 \times 10^{5}$ \\
\hline ser & 20 & ARS-BFGL-NGS-73590 & $39,761,822$ & $\mathrm{~A} / \mathrm{G}$ & 0.407 & 2.328 & 0.597 & 3.289 & $9.636 \times 10^{5}$ \\
\hline ser & 28 & BovineHD2800013250 & $45,702,356$ & $\mathrm{G} / \mathrm{A}$ & 0.463 & -2.383 & 0.574 & 3.547 & $3.252 \times 10^{5}$ \\
\hline
\end{tabular}

${ }^{\mathrm{a}}$ col and ser $=$ the concentration of albumin in colostrum and serum, respectively; ${ }^{\mathrm{b}}$ cow chromosome; ${ }^{\mathrm{c}}$ minor allele frequency; ${ }^{\mathrm{d}}$ standard error of the SNP effect; ${ }^{\mathrm{e}}$ contribution to genetic variance. 


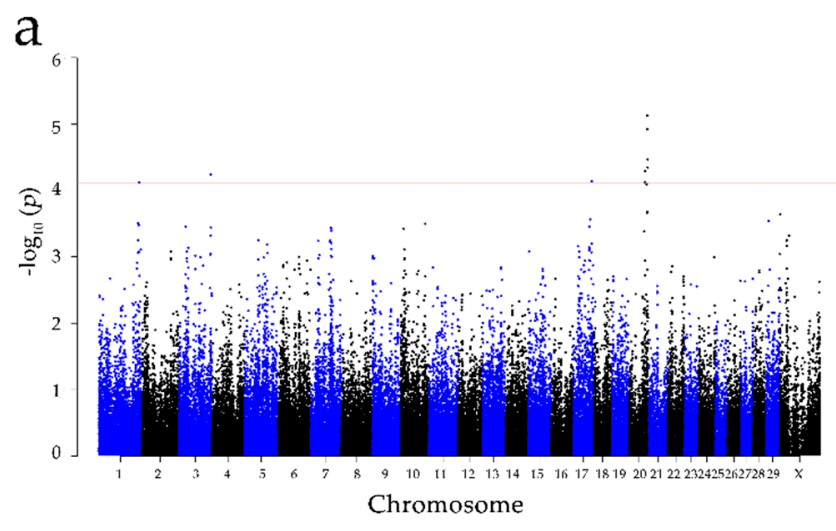

$\mathrm{b}$
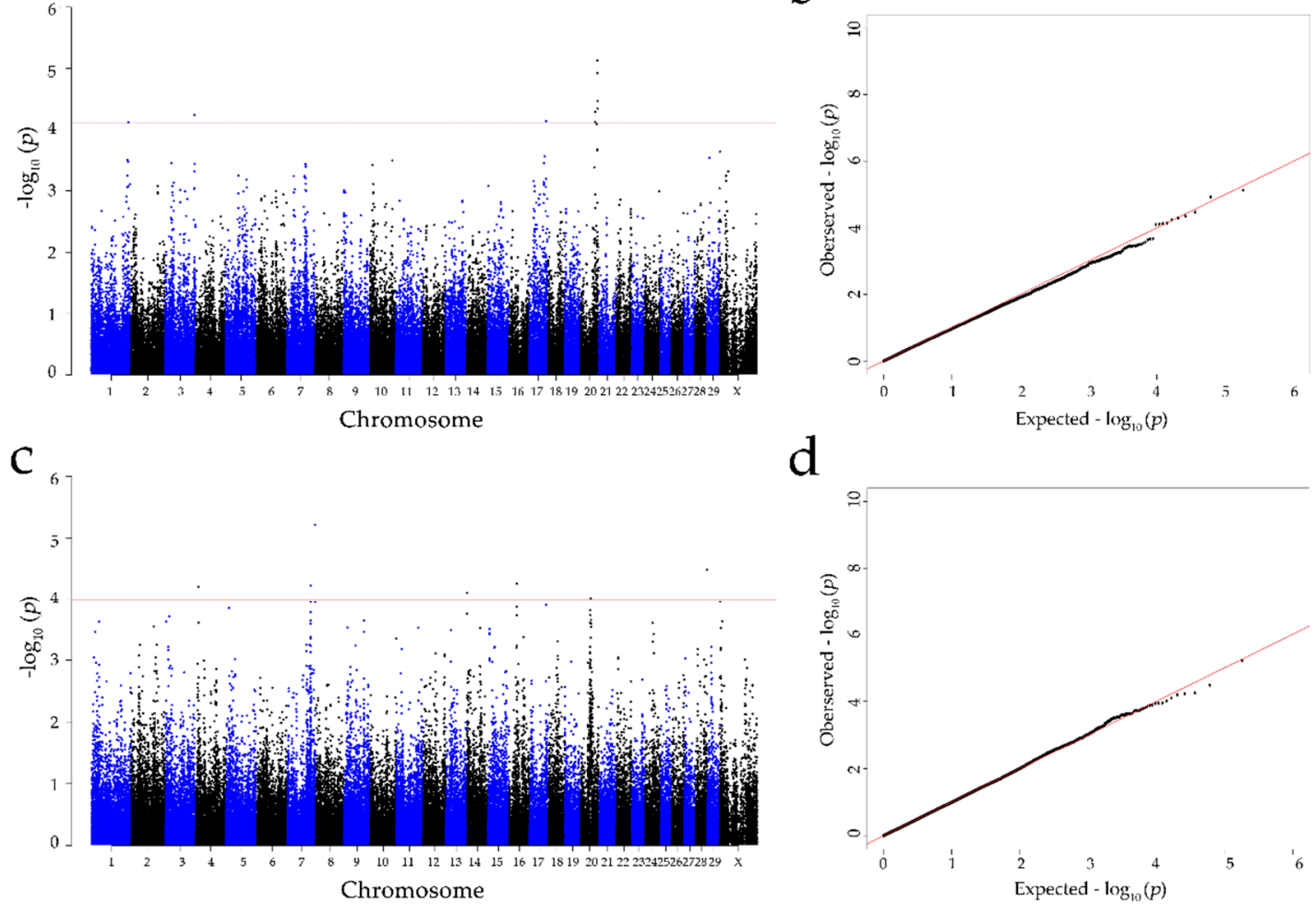

$\mathrm{d}$

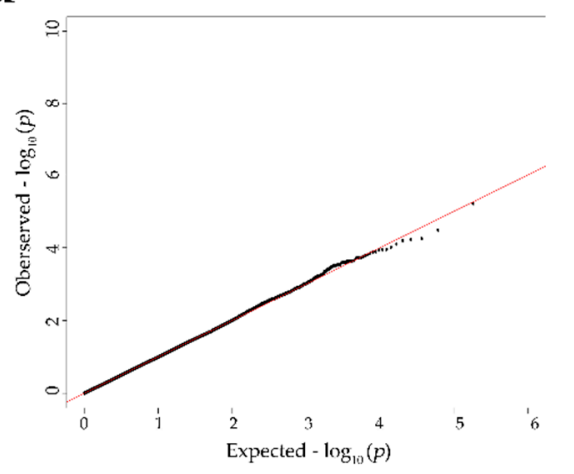

Figure 3. Manhattan and Q-Q plots of the observed $p$-values for the concentration of albumin in the colostrum and serum: $(\mathbf{a}, \mathbf{b})$ indicate the albumin concentration in colostrum; $(\mathbf{c}, \mathbf{d})$ indicate the albumin concentration in serum. The Manhattan plots present the $-\log _{10}$ values ( $p$-values) for the genome-wide SNPs ( $y$-axis) plotted against their respective positions on each chromosome ( $x$-axis); the horizontal red in the Manhattan plots present the thresholds with an FDR rate of $1 \%$ for albumin in colostrum $\left(7.85 \times 10^{5}\right)$ and serum $\left(1.01 \times 10^{5}\right)$. The Q-Q plots show the observed - $\log _{10}$-transformed $p$-values $\left(y\right.$-axis) and the expected $-\log _{10}$-transformed $p$-values ( $x$-axis).

\subsection{Candidate Genes and Functional Analysis}

After mapping to the bovine genome assembly UMD3.1.1, we found 42 genes within the region that were $1 \mathrm{Mbp}$ of up/downstream of the significant SNPs for the colostrum albumin concentration, including 36 protein-coding genes, 1 miRNA genes and 5 pseudogenes (Table S1). By performing GO terms and KEGG pathways analysis, RUNX family transcription factor 1 (RUNX1), carbonyl reductase 1 (CBR1) and OTU deubiquitinase with linear linkage specificity (OTULIN) were observed to be involved in the positive regulation of interleukin-2 production, oxidation-reduction process, negative regulation of nuclear factor (NF)-kappaB transcription factor activity and negative regulation of inflammatory response (Table S2). Hence, RUNX1 (BTA 1: 148.73 Mbp), CBR1 (BTA 1: 150.06 Mbp) and OTULIN (BTA 20: $\sim 58.58 \mathrm{Mbp}$ ) were eventually selected as the candidate genes for the colostrum albumin concentration (Table 3). 
Table 3. Candidate genes $1 \mathrm{Mbp}$ from the significant SNPs identified in the genome-wide association studies for the albumin concentration in colostrum and serum.

\begin{tabular}{|c|c|c|c|c|c|}
\hline Gene ID & Chr ${ }^{a}$ & Gene Name & Gene Start $(b p)^{b}$ & Gene End (bp) ${ }^{b}$ & Traits $^{c}$ \\
\hline ENSBTAG00000004742 & 1 & RUNX1 & $148,678,710$ & $148,773,781$ & $\mathrm{col}$ \\
\hline ENSBTAG00000023384 & 1 & CBR1 & $150,054,221$ & $150,064,637$ & col \\
\hline ENSBTAG00000003186 & 20 & OTULIN & $58,563,064$ & $58,596,022$ & col \\
\hline ENSBTAG00000044023 & 4 & CDK6 & $9,791,798$ & $10,039,688$ & ser \\
\hline ENSBTAG00000012235 & 14 & SHARPIN & $1,925,026$ & $1,929,354$ & ser \\
\hline ENSBTAG00000012232 & 14 & CYC1 & $1,930,183$ & $1,932,580$ & ser \\
\hline ENSBTAG00000014607 & 14 & EXOSC4 & $1,947,198$ & $1,949,074$ & ser \\
\hline ENSBTAG00000009677 & 14 & PARP10 & $2,024,591$ & $2,031,476$ & ser \\
\hline ENSBTAG00000008079 & 14 & NRBP2 & $2,154,132$ & $2,159,657$ & ser \\
\hline ENSBTAG00000034691 & 14 & GFUS & $2,288,555$ & $2,293,395$ & ser \\
\hline ENSBTAG00000016810 & 14 & PYCR3 & $2,301,587$ & $2,309,099$ & ser \\
\hline ENSBTAG00000014643 & 14 & EEF1D & $2,314,039$ & $2,326,727$ & ser \\
\hline ENSBTAG00000021474 & 14 & GSDMD & $2,341,282$ & $2,347,798$ & ser \\
\hline ENSBTAG00000005835 & 16 & PYCR2 & $29,695,733$ & $2,9699,696$ & ser \\
\hline ENSBTAG00000005077 & 28 & CXCL12 & $45,410,676$ & $45,418,794$ & ser \\
\hline
\end{tabular}

${ }^{\mathrm{a}}$ Cow chromosome number; ${ }^{\mathrm{b}}$ the position of gene was based on the UMD 3.1.1 assembly; ${ }^{\mathrm{c}}$ col and ser $=$ the concentration of albumin in colostrum and serum, respectively.

A total of 206 genes were obtained $1 \mathrm{Mbp}$ from the significant SNPs for the serum albumin concentration, containing 155 protein-coding genes, 5 miRNA genes and 46 pseudogenes (Table S1). Of these, the GO and KEGG results showed that 24 genes participated in the albumin-related terms and pathways, such as the oxidation-reduction process, regulation of inflammatory and immune response, and NF-kappa B and MAPK signaling pathway (Table S2). After comparing the physical positions of these 206 genes with the positions of the released QTLs for inflammation and immune capacity in cattle (27 August 2020, Cattle QTLdb), 138 genes were found located in the interval of these QTLs. Combining the results of the GO and KEGG with the known QTL data, 12 functional genes were identified as promising candidates related to the serum albumin concentration (Table 3 ), including cyclin-dependent kinase 6 (CDK6, BTA 4: 9.92 Mbp), SHANK-associated RH domain interactor (SHARPIN, BTA 14: 1.93 Mbp), cytochrome c1 (CYC1, BTA 14: 1.93 Mbp), exosome component 4 (EXOSC4, BTA 14: 1.95 Mbp), poly (ADP-ribose) polymerase family member 10 (PARP10, BTA 14: $2.03 \mathrm{Mbp}$ ), nuclear receptor binding protein 2 (NRBP2, BTA 14: $2.16 \mathrm{Mbp}$ ), GDP-L-fucose synthase (GFUS, BTA 14: 2.29 Mbp), pyrroline-5-carboxylate reductase 3 (PYCR3, BTA 14: 2.31 Mbp), eukaryotic translation elongation factor 1 delta (EEF1D, BTA 14: 2.32 Mbp), gasdermin D (GSDMD, BTA 14: $\sim 2.34 \mathrm{Mbp}$ ), pyrroline-5-carboxylate reductase 2 (PYCR2, BTA 16: 29.70 Mbp) and C-X-C motif chemokine ligand 12 (CXCL12, BTA 28: 45.41 Mbp).

\section{Discussion}

In this study, we identified nine and seven genome-wide significant SNPs (FDR at 1\%) associated with the albumin concentration in colostrum and serum in Chinese Holstein, respectively, using GWASs. For the significant SNPs captured in these two traits, no common genomic regions were shared. Hence, we calculated the correlations between these two traits using GCTA software and the phenotypic and genetic correlations were 0.011 and 0.0996 , respectively, suggesting a weak correlation between the colostrum and serum albumin concentration. This is likely the reason that no common genomic regions were identified in the GWAS for these two traits. Besides, albumin is produced by hepatocytes and the majority of the protein is immediately released into the blood circulation [12] and only small amounts of albumin in the blood enters the milk by tight junction [8]. These two different sources and transport mechanisms of albumin in colostrum and serum might have been the cause of the weak phenotypic and genetic correlations between these two traits.

Population stratification and family structure can cause a number of false positive results in GWASs [52]. After a proper correction, the $\lambda$ value should be close to 1 [53]. In the present study, the inflation factor $(\lambda)$ 
was 0.983 and 1.004 for the concentration of colostrum and serum albumin, respectively, indicating that the population stratification was successfully corrected by the appropriate model [51].

In this study, the MAF of each significant SNP ranged from 0.107 to 0.463 for the colostrum and serum albumin concentrations. This implied these SNPs could be used for marker-assisted selection or a genomic selection program through selecting the advantageous alleles with positive effects to accelerate the albumin concentration in colostrum and serum in dairy cattle, thereby increasing the disease-resistance ability of calves. The contribution to genetic variance of the SNPs were relatively high with a range of $2.55-4.091 \%$ for the colostrum and serum albumin concentrations. Previous studies indicated that the SNPs identified by GWASs generally explain only a small fraction of the heritability, while the SNP effects might be magnified when applying the mixed-model association (MLMA) methods by GCTA $[44,54,55]$. Due to the advantages of the MLMA method in GCTA, like the prevention of false positive associations and an increase in power obtained through the application of a correction that is specific to a specific structure, MLMA is still a popular method for complex traits in GWASs [54].

After the functional analysis of genes in the regions within a $1 \mathrm{Mbp}$ distance of the significant SNPs, 3 and 12 genes were identified as promising candidates for the concentration of colostrum and serum albumin in dairy cattle, respectively. Of these, $C B R 1$ and $C Y C 1$ were reported to be associated with the oxidation-reduction process. $C B R 1$ encodes the protein belonging to the short-chain dehydrogenases/reductases (SDR) family that acts as an NADP-dependent oxidoreductase in the oxidation-reduction process [56]. The $C Y C 1$ gene encodes a subunit of the cytochrome bc1 complex whose catalytic activity is required for the release of pro-apoptotic factors from mitochondria and the execution of the subsequent apoptotic steps [57-59]. It is well known that anti-oxidation is one of the most important properties of albumin. Remarkably, the oxidation-reduction process is the crucial part of an anti-inflammatory response, which demonstrates that the albumin in colostrum and serum is essential in anti-inflammation.

The other set of candidate genes, i.e., RUNX1, OTULIN, CDK6, SHARPIN, NRBP2, PYCR3, GSDMD, PYCR2 and CXCL12, were involved in immunity and inflammation. It has been proven that the mutations of RUNX1 initiate the hyperactivation of inflammatory and innate immunity, including the IL-6, TLR, NF-kappaB, IFN and TREM1 signaling pathways [60]. OTULIN is critical for restraining life-threatening spontaneous inflammation, maintaining immune homeostasis and activating NF-kappaB to promote the secretion of pro-inflammatory cytokines and restricts bacterial proliferation in infection [61,62]. CDK6 is required for the expression of inflammatory genes and is a critical regulator in the NF-kappaB signaling pathway, as well as contributing to cytokine production while inhibiting apoptosis [63,64]. SHARPIN regulates TLR3-mediated innate immunity, auto inflammation and the development of immunodeficiency $[65,66]$. The nuclear receptor binding protein, NRBP2, fights the infection of intracellular pathogens by regulating autophagy in the innate immune response [67]. PYCR2 and PYCR3 encode a protein that belongs to the pyrroline-5-carboxylate reductase family of enzymes that responds to genotoxic, inflammatory, nutrient and oxidative stress $[68,69]$. GSDMD encodes a member of the adermin family of pore-forming proteins implicated in the immune response [70], which controls the release of the proinflammatory cytokines IL-1B, IL-18 and pyroptotic cell death, and drive the inflammation in septic shock as well as the autoimmune diseases [71,72]. CXCL12 encodes a stromal cell-derived alpha chemokine member of the intercrine family and is involved in many diverse cellular functions, such as immune surveillance, inflammation response and tissue homeostasis [73-75]. Generally, all of these genes played vital roles in the inflammation and immune-related process, which indicated the potentially important roles of albumin in colostrum and serum in resistance to infectious diseases.

Resistance to viral infection is also a crucial capacity for the health and survival of calves. Herein, the candidate genes PARP10, EXOSC4, GFUS and EEF1D, involved in various viral infections, were identified. PARP10, a member of the poly (ADP-ribose) polymerases (PARPs) family, is related to immunity, metabolism, apoptosis and DNA damage repair [76], and could alter the cell cycle to inhibit virus replication during the process of avian influenza virus infection [77]. EXOSC4 participated in the regulation 
of anti-viral responses to decrease human papillomavirus infectivity of keratinocytes [78]. GFUS activated the immune-network to enhance the regulation of apoptosis, T cell homeostasis, neutrophil-mediated immunity, neutrophil chemotaxis, interleukin-8 production, inflammatory response, immune response, B-cell activation and MAPK activity activation during hepatitis C virus infection [79]. During human immunodeficiency virus 1 (HIV-1) infection, EEF1D interacted with HIV-1 transcription protein, resulting in the inhibition of the translation of host cell proteins but in an increase in the translation of viral proteins [80]. These studies suggested the importance of albumin together with these candidate genes in fighting infections caused by viruses.

Moreover, from a breeding perspective, the concentration of albumin in serum or milk is influenced by pathological and genetic factors, which highlights the possibility of albumin as a new trait to improve dairy cattle disease resistance. Nowadays, with the comprehensive implication of genomic selection in dairy cattle breeding, where high-density SNP chips, such as Illumina $50 \mathrm{~K}$ and GeneSeek $150 \mathrm{~K}$ chips, are widely used, most of SNPs are collected from the current SNP database and almost evenly distributed across the whole genome. Therefore, the significant SNPs and genes associated with albumin concentration could be put into such chips to improve the health and resistance to pathogens of newborns in dairy cattle.

\section{Conclusions}

In summary, our GWAS detected nine and seven genome-wide significant SNPs associated with the concentration of albumin in colostrum and serum, respectively. By integrated analysis of the biological functions of the genes that contain or close to $( \pm 1 \mathrm{Mbp})$ such significant SNPs and the known QTLs for inflammation and immunity capacity, RUNX1, CBR1 and OTULIN were selected as the candidate genes for the albumin concentration in colostrum. Meanwhile, 12 promising candidate genes were suggested for the albumin concentration in colostrum and serum of dairy cattle, including CDK6, SHARPIN, CYC1, EXOSC4, PARP10, NRBP2, GFUS, PYCR3, EEF1D, GSDMD, PYCR2 and CXCL12. Our results provided a genetic view on the regulation of albumin and fundamental information for the genetic improvement program on health and resistance traits in dairy cattle.

Supplementary Materials: The following are available online at http://www.mdpi.com/2076-2615/10/12/2211/s1. Supplementary File 1: MAP file of SNP data, Supplementary File 2: PED file of SNP data, Table S1: The features of genes contained or were close to $( \pm 1 \mathrm{Mbp})$ the significant SNPs for concentration of albumin in colostrum and serum, Table S2: Functional enrichment of the GO and KEGG analysis of 248 genes.

Author Contributions: Conceptualization, D.S. and B.H.; methodology, S.L. and Z.W.; software, S.L. and J.Z.; formal analysis, S.L. and L.X.; investigation, Z.W. and J.Z.; resources, D.S. and S.L.; data curation, D.S.; writing-original draft preparation, S.L.; writing-review and editing, D.S.; visualization, S.L.; supervision, D.S. and B.H.; project administration, D.S.; funding acquisition, D.S. All authors have read and agreed to the published version of the manuscript.

Funding: This research was funded by the National Natural Science Foundation of China $(31872330,31802041)$, Hebei Key Research and Development Program for Dairy Industry Revitalization (19226371D), Beijing Science and Technology Program (20200105, D171100002417001), and the Program for Changjiang Scholar and Innovation Research Team in University (IRT_15R62).

Acknowledgments: Thanks are due to the Beijing Dairy Cattle Center and the Beijing Sunlon Livestock Development Company Limited for care of the experimental animals and for assisting with the colostrum, serum and hair samples collection.

Conflicts of Interest: The authors declare no conflict of interest.

\section{References}

1. Boichard, D.; Brochard, M. New phenotypes for new breeding goals in dairy cattle. Animal 2012, 6, 544-550. [CrossRef]

2. Miglior, F.; Fleming, A.; Malchiodi, F.; Brito, L.F.; Martin, P.; Baes, C.F. A 100-Year Review: Identification and genetic selection of economically important traits in dairy cattle. J. Dairy Sci. 2017, 100, 10251-10271. [CrossRef] [PubMed] 
3. LeBlanc, S.J.; Lissemore, K.D.; Kelton, D.F.; Duffield, T.F.; Leslie, K.E. Major advances in disease prevention in dairy cattle. J. Dairy Sci. 2006, 89, 1267-1279. [CrossRef] [PubMed]

4. Trotz-Williams, L.A.; Leslie, K.E.; Peregrine, A.S. Passive immunity in Ontario dairy calves and investigation of its association with calf management practices. J. Dairy Sci. 2008, 91, 3840-3849. [CrossRef] [PubMed]

5. Raboisson, D.; Delor, F.; Cahuzac, E.; Gendre, C.; Sans, P.; Allaire, G. Perinatal, neonatal, and rearing period mortality of dairy calves and replacement heifers in France. J. Dairy Sci. 2013, 96, 2913-2924. [CrossRef] [PubMed]

6. Cabrera, R.A.; Lin, X.; Campbell, J.M.; Moeser, A.J.; Odle, J. Influence of birth order, birth weight, colostrum and serum immunoglobulin G on neonatal piglet survival. J. Anim. Sci. Biotechnol. 2012, 3, 42. [CrossRef] [PubMed]

7. Blum, J.W.; Hammon, H. Colostrum effects on the gastrointestinal tract, and on nutritional, endocrine and metabolic parameters in neonatal calves. Livest. Prod. Sci. 2000, 66, 151-159. [CrossRef]

8. Jordan, S.M.; Morgan, E.H. Albumin, transferrin and gamma-globulin metabolism during lactation in the rat. Q. J. Exp. Physiol. Cogn. Med. Sci. 1967, 52, 422-429. [CrossRef]

9. Schanbacher, F.L.; Smith, K.L. Formation and role of unusual whey proteins and enzymes: Relation to mammary function. J. Dairy Sci. 1975, 58, 1048-1062. [CrossRef]

10. Lascelles, A.K. The immune system on the ruminant mammary gland and its role in the control of mastitis. J. Dairy Sci. 1979, 62, 154-167. [CrossRef]

11. de Wit, J.N. Marschall Rhone-Poulenc Award Lecture. Nutritional and functional characteristics of whey proteins in food products. J. Dairy Sci. 1998, 81, 597-608. [CrossRef] [PubMed]

12. Rozga, J.; Piatek, T.; Malkowski, P. Human albumin: Old, new, and emerging applications. Ann. Transpl. 2013, 18, 205-217. [CrossRef]

13. Shamay, A.; Homans, R.; Fuerman, Y.; Levin, I.; Barash, H.; Silanikove, N.; Mabjeesh, S.J. Expression of albumin in nonhepatic tissues and its synthesis by the bovine mammary gland. J. Dairy Sci. 2005, 88, 569-576. [CrossRef] [PubMed]

14. Wilde, B.; Katsounas, A. Immune Dysfunction and Albumin-Related Immunity in Liver Cirrhosis. Mediat. Inflamm. 2019, 2019, 7537649. [CrossRef]

15. Poutrel, B.; Caffin, J.P.; Rainard, P. Physiological and Pathological Factors Influencing Bovine Serum-Albumin Content of Milk. J. Dairy Sci. 1983, 66, 535-541. [CrossRef] [PubMed]

16. Haenlein, G.F.; Schultz, L.H.; Zikakis, J.P. Composition of proteins in milk with varying leucocyte contents. J. Dairy Sci. 1973, 56, 1017-1024. [CrossRef]

17. Harmon, R.J.; Schanbacher, F.L.; Ferguson, L.C.; Smith, K.L. Concentration of lactoferrin in milk of normal lactating cows and changes occurring during mastitis. Am. J. Vet. Res. 1975, 36, 1001-1007.

18. Bannerman, D.D.; Paape, M.J.; Hare, W.R.; Sohn, E.J. Increased levels of LPS-binding protein in bovine blood and milk following bacterial lipopolysaccharide challenge. J. Dairy Sci. 2003, 86, 3128-3137. [CrossRef]

19. Nguyen, D.A.; Neville, M.C. Tight junction regulation in the mammary gland. J. Mammary Gland Biol. Neoplasia 1998, 3, 233-246. [CrossRef]

20. Sordillo, L.M.; Nickerson, S.C.; Akers, R.M.; Oliver, S.P. Secretion composition during bovine mammary involution and the relationship with mastitis. Int. J. Biochem. 1987, 19, 1165-1172. [CrossRef]

21. Riollet, C.; Rainard, P.; Poutrel, B. Differential induction of complement fragment C5a and inflammatory cytokines during intramammary infections with Escherichia coli and Staphylococcus aureus. Clin. Diagn. Lab. Immunol. 2000, 7, 161-167. [CrossRef] [PubMed]

22. Watanabe, A.; Yagi, Y.; Shiono, H.; Yokomizo, Y. Effect of intramammary infusion of tumour necrosis factor-alpha on milk protein composition and induction of acute-phase protein in the lactating cow. J. Vet. Med. B Infect. Dis. Vet. Public Health 2000, 47, 653-662. [CrossRef] [PubMed]

23. Leitner, G.; Chaffer, M.; Shamay, A.; Shapiro, F.; Merin, U.; Ezra, E.; Saran, A.; Silanikove, N. Changes in milk composition as affected by subclinical mastitis in sheep. J. Dairy Sci. 2004, 87, 46-52. [CrossRef] [PubMed]

24. Leitner, G.; Merin, U.; Silanikove, N. Changes in milk composition as affected by subclinical mastitis in goats. J. Dairy Sci. 2004, 87, 1719-1726. [CrossRef] [PubMed]

25. Bounous, G. Whey protein concentrate (WPC) and glutathione modulation in cancer treatment. Anticancer Res. 2000, 20, 4785-4792.

26. Hill, W.G.; Mackay, T.F. DS Falconer and Introduction to quantitative genetics. Genetics 2004, 167, $1529-1536$. 
27. Loomis, S.J.; Tin, A.; Coresh, J.; Boerwinkle, E.; Pankow, J.S.; Kottgen, A.; Selvin, E.; Duggal, P. Heritability analysis of nontraditional glycemic biomarkers in the Atherosclerosis Risk in Communities Study. Genet. Epidemiol. 2019, 43, 776-785. [CrossRef]

28. Forsblom, C.M.; Kanninen, T.; Lehtovirta, M.; Saloranta, C.; Groop, L.C. Heritability of albumin excretion rate in families of patients with Type II diabetes. Diabetologia 1999, 42, 1359-1366. [CrossRef]

29. Cecchinato, A.; Bobbo, T.; Ruegg, P.L.; Gallo, L.; Bittante, G.; Pegolo, S. Genetic variation in serum protein pattern and blood beta-hydroxybutyrate and their relationships with udder health traits, protein profile, and cheese-making properties in Holstein cows. J. Dairy Sci. 2018, 101, 11108-11119. [CrossRef]

30. Bondarenko, G.A.; Guseva, N.I.; Ptashevskaia, I.V.; Varnavskaia, N.V.; Peryshkova, T.A. Inheritability of blood metabolite concentrations in cattle at different age periods and seasons of the year. Genetika 1977, 13, 439-450.

31. Luke, T.D.W.; Nguyen, T.T.T.; Rochfort, S.; Wales, W.J.; Richardson, C.M.; Abdelsayed, M.; Pryce, J.E. Genomic prediction of serum biomarkers of health in early lactation. J. Dairy Sci. 2019, 102, 11142-11152. [CrossRef] [PubMed]

32. Zhang, H.; Wang, Z.; Wang, S.; Li, H. Progress of genome wide association study in domestic animals. J. Anim. Sci. Biotechnol. 2012, 3, 26. [CrossRef] [PubMed]

33. Oliveira, H.R.; Cant, J.P.; Brito, L.F.; Feitosa, F.L.B.; Chud, T.C.S.; Fonseca, P.A.S.; Jamrozik, J.; Silva, F.F.; Lourenco, D.A.L.; Schenkel, F.S. Genome-wide association for milk production traits and somatic cell score in different lactation stages of Ayrshire, Holstein, and Jersey dairy cattle. J. Dairy Sci. 2019, 102, 8159-8174. [CrossRef] [PubMed]

34. Meredith, B.K.; Kearney, F.J.; Finlay, E.K.; Bradley, D.G.; Fahey, A.G.; Berry, D.P.; Lynn, D.J. Genome-wide associations for milk production and somatic cell score in Holstein-Friesian cattle in Ireland. BMC Genet. 2012, 13, 21. [CrossRef]

35. Cole, J.B.; Wiggans, G.R.; Ma, L.; Sonstegard, T.S.; Lawlor, T.J., Jr.; Crooker, B.A.; Van Tassell, C.P.; Yang, J.; Wang, S.; Matukumalli, L.K.; et al. Genome-wide association analysis of thirty one production, health, reproduction and body conformation traits in contemporary U.S. Holstein cows. BMC Genom. 2011, 12, 408. [CrossRef]

36. de Klerk, B.; Emam, M.; Thompson-Crispi, K.A.; Sargolzaei, M.; van der Poel, J.J.; Mallard, B.A. A genome-wide association study for natural antibodies measured in blood of Canadian Holstein cows. BMC Genom. 2018, 19, 694. [CrossRef]

37. Li, C.; Sun, D.; Zhang, S.; Wang, S.; Wu, X.; Zhang, Q.; Liu, L.; Li, Y.; Qiao, L. Genome wide association study identifies 20 novel promising genes associated with milk fatty acid traits in Chinese Holstein. PLoS ONE 2014, 9, e96186. [CrossRef]

38. Sodeland, M.; Kent, M.P.; Olsen, H.G.; Opsal, M.A.; Svendsen, M.; Sehested, E.; Hayes, B.J.; Lien, S. Quantitative trait loci for clinical mastitis on chromosomes 2, 6, 14 and 20 in Norwegian Red cattle. Anim. Genet. 2011, 42, 457-465. [CrossRef]

39. Meredith, B.K.; Berry, D.P.; Kearney, F.; Finlay, E.K.; Fahey, A.G.; Bradley, D.G.; Lynn, D.J. A genome-wide association study for somatic cell score using the Illumina high-density bovine beadchip identifies several novel QTL potentially related to mastitis susceptibility. Front. Genet. 2013, 4, 229. [CrossRef]

40. Wu, X.; Lund, M.S.; Sahana, G.; Guldbrandtsen, B.; Sun, D.; Zhang, Q.; Su, G. Association analysis for udder health based on SNP-panel and sequence data in Danish Holsteins. Genet. Sel. Evol. 2015, 47, 50. [CrossRef]

41. Cordero-Solorzano, J.; Parmentier, H.K.; Arts, J.A.J.; van der Poel, J.; de Koning, D.J.; Bovenhuis, H. Genome-wide association study identifies loci influencing natural antibody titers in milk of Dutch Holstein-Friesian cattle. J. Dairy Sci. 2019, 102, 11092-11103. [CrossRef] [PubMed]

42. Purcell, S.; Neale, B.; Todd-Brown, K.; Thomas, L.; Ferreira, M.A.; Bender, D.; Maller, J.; Sklar, P.; de Bakker, P.I.; Daly, M.J.; et al. PLINK: A tool set for whole-genome association and population-based linkage analyses. Am. J. Hum. Genet. 2007, 81, 559-575. [CrossRef] [PubMed]

43. Wiggans, G.R.; Sonstegard, T.S.; Vanraden, P.M.; Matukumalli, L.K.; Schnabel, R.D.; Taylor, J.F.; Schenkel, F.S.; Van Tassell, C.P. Selection of single-nucleotide polymorphisms and quality of genotypes used in genomic evaluation of dairy cattle in the United States and Canada. J. Dairy Sci. 2009, 92, 3431-3436. [CrossRef] [PubMed]

44. Yang, J.; Lee, S.H.; Goddard, M.E.; Visscher, P.M. GCTA: A tool for genome-wide complex trait analysis. Am. J. Hum. Genet. 2011, 88, 76-82. [CrossRef] 
45. Johnson, R.C.; Nelson, G.W.; Troyer, J.L.; Lautenberger, J.A.; Kessing, B.D.; Winkler, C.A.; O’Brien, S.J. Accounting for multiple comparisons in a genome-wide association study (GWAS). BMC Genom. 2010, 11, 724. [CrossRef]

46. Benjamini, Y.; Hochberg, Y. Controlling the False Discovery Rate-A Practical and Powerful Approach to Multiple Testing. J. R. Stat. Soc. B 1995, 57, 289-300. [CrossRef]

47. Weller, J.I.; Song, J.Z.; Heyen, D.W.; Lewin, H.A.; Ron, M. A new approach to the problem of multiple comparisons in the genetic dissection of complex traits. Genetics 1998, 150, 1699-1706.

48. Aulchenko, Y.S.; Ripke, S.; Isaacs, A.; Van Duijn, C.M. GenABEL: An R library for genome-wide association analysis. Bioinformatics 2007, 23, 1294-1296. [CrossRef]

49. The R Development Core Team. R: A Language and Environment for Statistical Computing; The R Development Core Team: Vienna, Austria, 2015.

50. Turner, S.D. qqman: An R package for visualizing GWAS results using Q-Q and manhattan plots. bioRxiv 2014. [CrossRef]

51. Price, A.L.; Zaitlen, N.A.; Reich, D.; Patterson, N. New approaches to population stratification in genome-wide association studies. Nat. Rev. Genet. 2010, 11, 459-463. [CrossRef]

52. Haldar, T.; Ghosh, S. Effect of Population Stratification on False Positive Rates of Population-Based Association Analyses of Quantitative Traits. Ann. Hum. Genet. 2012, 76, 237-245. [CrossRef] [PubMed]

53. Devlin, B.; Roeder, K. Genomic control for association studies. Biometrics 1999, 55, 997-1004. [CrossRef] [PubMed]

54. Yang, J.; Zaitlen, N.A.; Goddard, M.E.; Visscher, P.M.; Price, A.L. Advantages and pitfalls in the application of mixed-model association methods. Nat. Genet. 2014, 46, 100-106. [CrossRef] [PubMed]

55. Kumar, S.K.; Feldman, M.W.; Rehkopf, D.H.; Tuljapurkar, S. Correction for Krishna Kumar et al., Limitations of GCTA as a solution to the missing heritability problem. Proc. Natl. Acad. Sci. USA 2016, 113, E813. [CrossRef]

56. Barracco, V.; Moschini, R.; Renzone, G.; Cappiello, M.; Balestri, F.; Scaloni, A.; Mura, U.; Del-Corso, A. Dehydrogenase/reductase activity of human carbonyl reductase 1 with NADP $(\mathrm{H})$ acting as a prosthetic group. Biochem. Biophys. Res. Commun. 2020, 522, 259-263. [CrossRef]

57. Kagan, V.E.; Tyurin, V.A.; Jiang, J.F.; Tyurina, Y.Y.; Ritov, V.B.; Amoscato, A.A.; Osipov, A.N.; Belikova, N.A.; Kapralov, A.A.; Kini, V.; et al. Cytochrome c acts as a cardiolipin oxygenase required for release of proapoptotic factors. Nat. Chem. Biol. 2005, 1, 223-232. [CrossRef]

58. Belikova, N.A.; Vladimirov, Y.A.; Osipov, A.N.; Kapralov, A.A.; Tyurin, V.A.; Potapovich, M.V.; Basova, L.V.; Peterson, J.; Kurnikov, I.V.; Kagan, V.E. Peroxidase activity and structural transitions of cytochrome c bound to cardiolipin-containing membranes. Biochemistry 2006, 45, 4998-5009. [CrossRef]

59. Kagan, V.E.; Bayir, H.A.; Belikova, N.A.; Kapralov, O.; Tyurina, Y.Y.; Tyurin, V.A.; Jiang, J.F.; Stoyanovsky, D.A.; Wipf, P.; Kochanek, P.M.; et al. Cytochrome c/cardiolipin relations in mitochondria: A kiss of death. Free Radic. Biol. Med. 2009, 46, 1439-1453. [CrossRef]

60. Ritter, M.; Klimiankou, M.; Klimenkova, O.; Schambach, A.; Hoffmann, D.; Schmidt, A.; Kanz, L.; Link, D.C.; Welte, K.; Skokowa, J. Cooperating, congenital neutropenia-associated Csf3r and Runx1 mutations activate pro-inflammatory signaling and inhibit myeloid differentiation of mouse HSPCs. Ann. Hematol. 2020, 99, 2329-2338. [CrossRef]

61. Damgaard, R.B.; Walker, J.A.; Marco-Casanova, P.; Morgan, N.V.; Titheradge, H.L.; Elliott, P.R.; McHale, D.; Maher, E.R.; McKenzie, A.N.J.; Komander, D. The Deubiquitinase OTULIN Is an Essential Negative Regulator of Inflammation and Autoimmunity. Cell 2016, 166, 1215-1230. [CrossRef]

62. van Wijk, S.J.L.; Fricke, F.; Herhaus, L.; Gupta, J.; Hotte, K.; Pampaloni, F.; Grumati, P.; Kaulich, M.; Sou, Y.S.; Komatsu, M.; et al. Linear ubiquitination of cytosolic Salmonella Typhimurium activates NF-kappaB and restricts bacterial proliferation. Nat. Microbiol. 2017, 2, 17066. [CrossRef] [PubMed]

63. Uras, I.Z.; Maurer, B.; Nivarthi, H.; Jodl, P.; Kollmann, K.; Prchal-Murphy, M.; Milosevic Feenstra, J.D.; Zojer, M.; Lagger, S.; Grausenburger, R.; et al. CDK6 coordinates JAK2 (V617F) mutant MPN via NF-kappaB and apoptotic networks. Blood 2019, 133, 1677-1690. [CrossRef] [PubMed]

64. Buss, H.; Handschick, K.; Jurrmann, N.; Pekkonen, P.; Beuerlein, K.; Muller, H.; Wait, R.; Saklatvala, J.; Ojala, P.M.; Schmitz, M.L.; et al. Cyclin-dependent kinase 6 phosphorylates NF-kappaB P65 at serine 536 and contributes to the regulation of inflammatory gene expression. PLoS ONE 2012, 7, e51847. [CrossRef] 
65. Zinngrebe, J.; Rieser, E.; Taraborrelli, L.; Peltzer, N.; Hartwig, T.; Ren, H.; Kovacs, I.; Endres, C.; Draber, P.; Darding, M.; et al. LUBAC deficiency perturbs TLR3 signaling to cause immunodeficiency and autoinflammation. J. Exp. Med. 2016, 213, 2671-2689. [CrossRef] [PubMed]

66. Kasirer-Friede, A.; Tjahjono, W.; Eto, K.; Shattil, S.J. SHARPIN at the nexus of integrin, immune, and inflammatory signaling in human platelets. Proc. Natl. Acad. Sci. USA 2019, 116, 4983-4988. [CrossRef]

67. Hanwei, J.; Nie, X.; Zhu, H.; Li, B.; Pang, F.; Yang, X.; Cao, R.; Yang, X.; Zhu, S.; Peng, D.; et al. miR-146b-5p Plays a Critical Role in the Regulation of Autophagy in per Brucella melitensis-Infected RAW264.7 Cells. Biomed. Res. Int. 2020, 2020, 1953242. [CrossRef]

68. Phang, J.M.; Pandhare, J.; Liu, Y. The metabolism of proline as microenvironmental stress substrate. J. Nutr. 2008, 138, 2008S-2015S. [CrossRef]

69. Kuo, M.L.; Lee, M.B.; Tang, M.; den Besten, W.; Hu, S.; Sweredoski, M.J.; Hess, S.; Chou, C.M.; Changou, C.A.; $\mathrm{Su}, \mathrm{M}$; et al. PYCR1 and PYCR2 Interact and Collaborate with RRM2B to Protect Cells from Overt Oxidative Stress. Sci. Rep. 2016, 6, 18846. [CrossRef]

70. Sollberger, G.; Choidas, A.; Burn, G.L.; Habenberger, P.; Di Lucrezia, R.; Kordes, S.; Menninger, S.; Eickhoff, J.; Nussbaumer, P.; Klebl, B.; et al. Gasdermin D plays a vital role in the generation of neutrophil extracellular traps. Sci. Immunol. 2018, 3, eaar6689. [CrossRef]

71. Orning, P.; Lien, E.; Fitzgerald, K.A. Gasdermins and their role in immunity and inflammation. J. Exp. Med. 2019, 216, 2453-2465. [CrossRef]

72. Li, S.; Wu, Y.; Yang, D.; Wu, C.; Ma, C.; Liu, X.; Moynagh, P.N.; Wang, B.; Hu, G.; Yang, S. Gasdermin $\mathrm{D}$ in peripheral myeloid cells drives neuroinflammation in experimental autoimmune encephalomyelitis. J. Exp. Med. 2019, 216, 2562-2581. [CrossRef] [PubMed]

73. Janssens, R.; Struyf, S.; Proost, P. The unique structural and functional features of CXCL12. Cell Mol. Immunol. 2018, 15, 299-311. [CrossRef] [PubMed]

74. Tachibana, K.; Hirota, S.; Iizasa, H.; Yoshida, H.; Kawabata, K.; Kataoka, Y.; Kitamura, Y.; Matsushima, K.; Yoshida, N.; Nishikawa, S.; et al. The chemokine receptor CXCR4 is essential for vascularization of the gastrointestinal tract. Nature 1998, 393, 591-594. [CrossRef] [PubMed]

75. Ma, Q.; Jones, D.; Borghesani, P.R.; Segal, R.A.; Nagasawa, T.; Kishimoto, T.; Bronson, R.T.; Springer, T.A. Impaired B-lymphopoiesis, myelopoiesis, and derailed cerebellar neuron migration in CXCR4- and SDF-1-deficient mice. Proc. Natl. Acad. Sci. USA 1998, 95, 9448-9453. [CrossRef] [PubMed]

76. Kaufmann, M.; Feijs, K.L.; Luscher, B. Function and regulation of the mono-ADP-ribosyltransferase ARTD10. Curr. Top Microbiol. Immunol. 2015, 384, 167-188. [CrossRef] [PubMed]

77. Yu, M.; Zhang, C.; Yang, Y.; Yang, Z.; Zhao, L.; Xu, L.; Wang, R.; Zhou, X.; Huang, P. The interaction between the PARP10 protein and the NS1 protein of H5N1 AIV and its effect on virus replication. Virol. J. 2011, 8, 546. [CrossRef] [PubMed]

78. Sun, Y.Z.; Li, J.F.; Wei, Z.D.; Jiang, H.H.; Hong, Y.X.; Zheng, S.; Qi, R.Q.; Gao, X.H. Proteomic and bioinformatic analysis of condyloma acuminata: Mild hyperthermia treatment reveals compromised HPV infectivity of keratinocytes via regulation of metabolism, differentiation and anti-viral responses. Int. J. Hyperth. 2019, 36, 383-393. [CrossRef]

79. Wang, L.; Huang, J.; Jiang, M.; Lin, H. Tissue-specific transplantation antigen P35B (TSTA3) immune response-mediated metabolism coupling cell cycle to postreplication repair network in no-tumor hepatitis/cirrhotic tissues (HBV or HCV infection) by biocomputation. Immunol. Res. 2012, 52, 258-268. [CrossRef]

80. Rotger, M.; Dalmau, J.; Rauch, A.; McLaren, P.; Bosinger, S.E.; Martinez, R.; Sandler, N.G.; Roque, A.; Liebner, J.; Battegay, M.; et al. Comparative transcriptomics of extreme phenotypes of human HIV-1 infection and SIV infection in sooty mangabey and rhesus macaque. J. Clin. Investig. 2011, 121, 2391-2400. [CrossRef]

Publisher's Note: MDPI stays neutral with regard to jurisdictional claims in published maps and institutional affiliations. 